\title{
16世紀後半ヴェネツィアにおけるサン・カッシアーノ地区の 劇場建設と上演について \\ STUDY ON THE CONSTRUCTION AND THE PLAY OF TWO THEATERS IN THE PARISH OF SAN CASSIANO IN THE LATE 16th CENTURY VENICE
}

\author{
青木 香代子* \\ Kayoko AOKI
}

\begin{abstract}
Two theaters for comedies built in the parish of San Cassiano, Venice in 1581 are studied in this paper by researching the manuscripts kept in the Archivio di Stato di Venezia. They are commonly known as one of the oldest theaters in Europe. However, because of lack of buildings and visual materials, it is still difficult to clarify their forms and the functions. In addition, the documents like the records of the Council of Ten do not give us sufficient information. In this study, the nobles who owned these theaters and actors are pointed out, then their purposes of the play and their roles as constructor are examined through the manuscripts to reveal the theatrical context of the late 16th century Venice
\end{abstract}

Keywords: Italy, Venice, Teatro Michiel, Teatro Tron, the parish of San Cassiano

イタリア, ヴェネツィア, テアトロ・ミキェル, テアトロ・トロン, サン・カッシアーノ地区

1 はじめに

\section{1-1 研究の背景と目的}

中世以降のイタリアでは、世俗的な祝祭における演劇は専用の施 設を持たず、パラッツォ内の広間、中庭あるいは広場等に仮設の舞 台や観客席を設えて催されてきたが、16 世紀後半になると各地で一 時的な使用を目的とするのではない多様な劇場建築が現れるように なる。その多くは為政者による政治活動として祝祭を演出するため につくられ、単に演劇が展開する場であっただけではなく都市の文 化・社会的背景を表象するものであった

一方ヴェネツィアでは、フランチェスコ・サンソヴィーノ゙が 1582 年に出版した『高貴かつ唯一の都市ヴェネツィア』と題した著名な 案内書虾、実に美しい 2 つ劇場があったことを記している。 所有した貴族の名からテアトロ・ミキエル、テアトロ・トロンと呼 ばれるこの 2 つの劇場は共にサン・カッシアーノ地区に位置し、ヴェ ネツィアにおいて常設の劇場として史料上に初めて登場するもので ある゙。 。たイタリア全体の中でも最初期に建設された劇場であった と考えられているがその様態は未だほとんど明らかにされていない。 本研究は、イタリア各地で専用の劇場建築が誕生し始めた 16 世紀 後半に着目し、その最も初期の例としてヴェネッィアのサン・カッシ アーノ地区におけるこの 2 つの劇場を対象とする。劇場という新し い建築は、文化的・社会的な要求を包括し、様々な試行錯誤の結果 成立したものである。サン・カッシアーノ地区に建設された 2 つの劇 場は、定着したビルディング・タイプとして劇場が社会・文化の中 に位置づけられる以前の萌芽的現象であるがゆえに、ヴェネツィア の社会・文化の特質を如実に映し出すものであったのではと筆者は 考えている。それが研究の動機である。

本研究の第一稿として、まずテアトロ・ミキェル、テアトロ・ト
ロンの建設と上演について劇場を所有した貴族と役者に着目し、そ の実態を分析し考察する。さらに次稿では、劇場のより具体的な形 態と劇場が建設されたサン・カッシアーノ地区の特質について検証 し、本稿とあわせて $2 つ の$ 劇場の様態を明らかにしていきたい。

\section{$1-2$ 既往の研究}

16 世紀のヴェネツィアにおける祝祭・演劇に関しては、多くの側 面から論究されている。なかでも貴族団体コンパニーア・デッラ・ カルツァとその祝祭に関するL.ヴェントゥーリの研究 (1909 年) $)^{5}$ 、

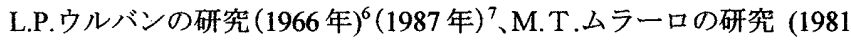
年)等により少しづつ進展をみせている。しかし、いずれも社会史的 観点から祝祭を論じたもので、そのための空間自体に関する考察は 十分になされていない。

$\mathrm{R}$.ジャツォットによる研究 $(1967 \text { 年 })^{10}$ は、多くの一次史料を使用 し、主に劇場を建設・運営した貴族間の摩擦、劇場内でのボックス 席の所有等に焦点を当てた優れた研究として評価できる。しかし、 これは $17 \cdot 18$ 世紀の劇場が対象とされている。より建築学的視座に よる研究であるL、ゾルツイらによる展覧会の図録 (1971 年) $)^{11} 、 \mathrm{~N}$. マンジー二の研究 (1974 年) ${ }^{12}$ は、他都市の劇場研究に比べ遅れをと っていたヴェネツィア劇場研究を大きく進展させるものであった。 続いてF.マンチーニ、M.T.ムラーロ、E.ポヴオレードによりヴェネ ツィアに限らずヴェネト地方全体の劇場を対象にした研究（1996 年) ${ }^{13}$ がまとめられたが、そのいずれも 19 世紀までにヴェネツィアに 建設された 15 以上の劇場を紹介したもので、史料が比較的多く残さ れている $17 \cdot 18$ 世紀に重点が置かれている。近年ではE.J.ジョン ソンが 16 世紀後半のサン・カッシアーノ地区の劇場に関する研究 $(2002 \text { 年 })^{14}$ をとめた。しかし、これは先行研究でも使用されてきた

\footnotetext{
* 東京芸術大学大学院美術研究科 博士後期課程 建築専攻 修士 (芸術)

Doctoral Course (Architecture), Graduate School of Fine Arts, Tokyo National University of Fine Arts and Music, M. Fine Arts.
} 
十人委員会に関する史料等を再読したうえで、閉場時期に関して有 力な説を提示したにとどまっている。以上のように、17 世紀以前の 劇場建設と上演を組織した主体という観点からサン・カッシアーノ 地区の劇場の様態を考察する研究は未だに着手されていない。

\section{1-3 史料}

サン・カッシアーノ地区の 2 つの劇場はいずれも現存せず、さら に都市内にその遺構もみられない。また図面・絵画などの図像史料 も 18 世紀におこなわれたテアトロ・トロンの 2 度目の再建以前のも のは現在まで残されていない ${ }^{15}$ 。以上から建築物ならびに図像による 証拠を用いた研究によって 16 世紀後半の建設当時の様態を明らかに することは不可能であり、現存する文書における当時の記述から検 証しなけれぱならない。

多岐に渡る職権を有していた元老院 Senato では、都市の中でも比 較的重要な建設について討議した事例が稀にあるが、その議事録 registro や下書き filza の中に劇場に関わる記録は見られない。。さら にその執行機関であるコッレージョ Collegio でも取り扱われていな い。また当時は新しい建築の計画または用途の変更に関して都市の 治安維持と風紀の監視を受けもった十人委員会 Consiglio dei Dieci ${ }^{17}$ で監督される例が多く見られる。この十人委員会の議事録における 劇場に関する記述は 1879 年にG.スフォルツァによってまとめられ ${ }^{18} 、$ 現在でもヴェネツィア劇場研究の基盤のひとつとなっている。しか しサン・カッシアーノ地区の劇場に関しては、各年毎にカーニバル期 間の上演許可が議題にあがっているにすぎず、劇場の様態に関わる 詳細な情報を得ることはできない。また、通常これらの議事録には 具体的な発言等は記されず、そこから劇場の様態を特定していくこ とは極めて困難である。

以上の経緯から本研究は、2つの劇場建設にミキエル家、トロン家 という貴族が関わっていたことに着目し、より個人的な内容が記さ れる書簡や公証人の元で作成された手稿等を主たる原史料として用 い、その様態を明らかにしようとするものである19。

\section{2 劇場の存続期間}

テアトロ・ミキエルについて最初に登場する史料は、 1581 年 2 月 2 日 ${ }^{20}$ 、ヴェネツィアの公証人フランチェスコ・モンドのもとで作成さ

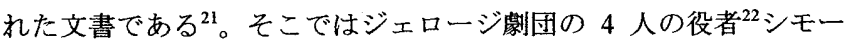
ネ・コドゥッシ23、オラッィオ・デッラ・トッレ24、ジュリオ・パス

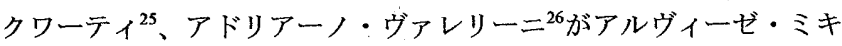
エルとその兄弟に対し、同年末に始まるカーニバルの期間に喜劇を 上演するための場所を建設することを求めている。一方テアトロ・ト ロンについては、劇場建設以前に記された文書は現存しない27。しか し、エットーレ・トロンが 1582 年 1 月 4 日の日付でエステ家のアル フォンソ二世に宛てた文書からは、当時既に劇場を所有していたこ とが分かる ${ }^{28}$ 。さらに、1581 年9月 25 日の十人委員会の議事録から は「喜劇を上演する1つ以上の場所」が存在したことが明らかであ $~^{29}{ }^{29}$ これは、同委員会における喜劇上演の許可をめぐる討議の中で、 場所に関する初めての言及である。以上から 2 つの劇場は 1581 年に 完成、開場したと考えられる。

ヴェネツィアでは 1508 年 12 月 29 日以降、喜劇、悲劇、牧歌劇の 上演は十人委員会からの許可を得ることが義務付けられている。な
かでも喜劇には若者を随落させるような淫らで不真面目な言葉の使 用がみられるとして特に厳しく取締りがされていた ${ }^{30}$ 。人委員会に おいて喜劇上演が禁止された期間中、実際には不法に上演した劇団 が存在したことは明らかだが31、テアトロ・ミキエルとテアトロ・ト ロンで上演した劇団は、禁止期間中に同委員会の委員長に直接手紙 を出し許可を請願していることから、正式な許可を得て上演するこ とを望んでいたと考えられる ${ }^{32}$ 。また不法な上演を避けようとしたこ とは、ヴェネツィアで上演が禁止された年には他の都市で活動した 記録があることからも推定できる33。以上から 2 つの劇場の上演時期 は十人委員会による喜劇上演に関する決議に概ね対応するといえる。 表 1 に示すように 1582 年 12 月 17 日以前は厳格な条件つきではあ るものの喜劇上演が行われていた。1582 年から続くカーニバル中の 1583 年 1 月には 2 度にわたり討議されたが、上演許可は与えられて いない。翌 1584 年にはカーニバル中の上演について討議された記録 は無いが、1585 年 2 月 8 日の文書には劇団から上演許可を請う文書 が十人委員会に送られたと記されていることから、1584年から 1585 年にかけてのカーニバル当初は上演が行われていなかったと考える。 その後、残りのカーニバル期間中の上演に関して討議されるが多数 決による結果は決裂し、2 度目の投票が行われた記録があるものの結

\section{表1 十人委員会による喜劇上演に関する決議}

\begin{tabular}{|c|c|c|c|}
\hline 更料名 & 日付 & 討識の主な内容 & 決軣 \\
\hline $\begin{array}{l}\text { Registro.35, } \\
\text { c. } 118 \mathrm{v} \text {. }\end{array}$ & 1580.12 .22 & $\begin{array}{l}\text { 1月1日からカーニバルの期間中、質素、誠実な内容で、チ } \\
\text { 前4時までに終えるというう条件で喜劇上演を許可する。 }\end{array}$ & 可決 \\
\hline $\begin{array}{l}\text { Registro.36, } \\
\text { c.9r. }\end{array}$ & 1581.9 .25 & 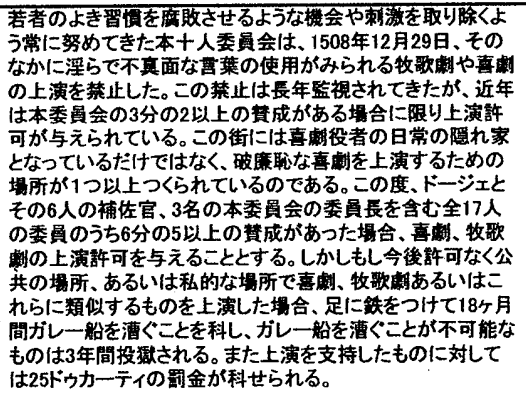 & 可沃 \\
\hline $\begin{array}{l}\text { Registro.36, } \\
\text { cc.178v. }-179 r .\end{array}$ & 1582.12 .17 & 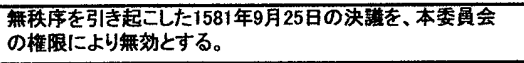 & 可決 \\
\hline $\begin{array}{l}\text { Registro.36, } \\
\text { c.180v. }\end{array}$ & 1583.7 .5 & 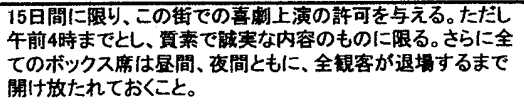 & 否決 \\
\hline $\begin{array}{l}\text { Registro.36, } \\
\text { c.181r. }\end{array}$ & 1583.1 .14 & 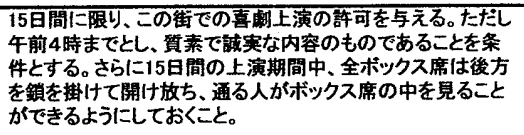 & 否決 \\
\hline$\overline{\text { Filza.158 }}$ & 1585.2 .8 & 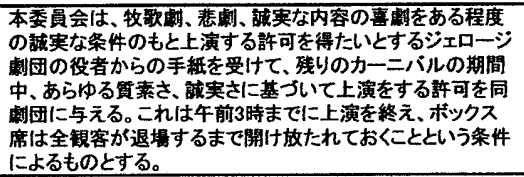 & 保要 \\
\hline $\begin{array}{l}\text { Registro.38, } \\
\text { c.81v. }\end{array}$ & 1586.1 .14 & 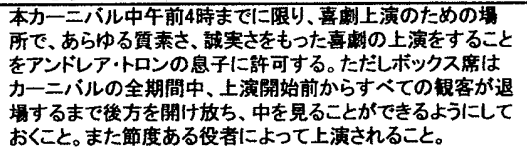 & 否決 \\
\hline $\begin{array}{l}\text { Registro.38, } \\
\text { cc.81v.-82r. }\end{array}$ & 1586.1 .14 & 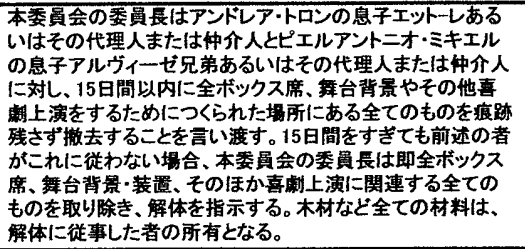 & 可決 \\
\hline
\end{tabular}


果は不明である。しかし 1585 年にアルヴィーゼ・トロンが同委員会 に送った文書には、劇場では建設後の数年間上演が行われた後、す ぐに禁止令が出されたと記されている34。以上から 1584 年から 1585 年にかけてのカーニバルでは上演が行われなかったことがわかる。

1586 年 1 月 14 日には再度上演許可が否決されている。さらに同日 の日付けで十人委員会の委員長から、アルヴィーゼ・ミキエル兄弟 とアルヴィーゼ・トロン兄弟に対し、15 日以内に劇場を解体するよ う言い渡されている ${ }^{35}$ 。

以上から、2つの劇場は常設の劇場として 1581 年に建設され、1586 年に解体が指示されるまで 4 年以上の間存続したが、実際に上演が 行われたのは 1582 年 12 月 17 日までの期間のみであったと考える。

\section{3 劇場の所有者}

テアトロ・ミキエルは、 1582 年 3 月に作成された十分の一税申告書 Condizioni di Decima から、ドルソドゥーロ区のサン・バジーリオに 住むアルヴィーゼ・ミキエル兄弟の所有であったことが明らかにな っている ${ }^{36}$ 。この申告書は、アルヴィーゼと 2 人以上の兄弟の連名で

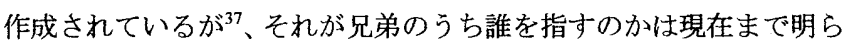
かにされてこなかった。1614 年の日付があるジョヴァンニ・バッティ スタ・ミキエルの遺言書 ${ }^{38}$ には、サン・カッシアーノ地区にかつて劇 場として使用されていた倉庫を所有し、これを弟アゴスティーノに 譲ることが記されている。またアルヴィーゼ・ミキエルも1616 年に 作成した遺言書 ${ }^{39}$ の中で同様の倉庫をアゴスティーノに譲ると記し ている。アルヴィーゼ、ジョヴァンニ・バッティスタ共に財産の多 くを妹のチェチリアと、異母弟であるピエロ ${ }^{40} に$ 遺している一方でサ ン・カッシアーノ地区の倉庫に限りアゴスティーノに譲っているこ とから、劇場は 6 人の男兄弟の中でアルヴィーゼとジョヴァンニ・ バッティスタ、アゴスティーノの3人で所有していたと考えられる。

一方テアトロ・トロンに関しては、サン・マルコ区のサン・ベネデ ットに住むアンドレア・トロン、エットーレ・トロンによる 1582 年の 十分の一税申告の中に「サン・カッシアーノ地区に所有する現在は まったく収入を得ていない喜劇を上演する場所」に関する項目が認 められる4!。その後アンドレアの死去から間もない 1586 年には、当 時 10 歳だった息子アルヴィーゼの名で十人委員会に劇場での上演を 許可するように求めた文書が存在する ${ }^{42}$ 。さらに、同委員会から通達

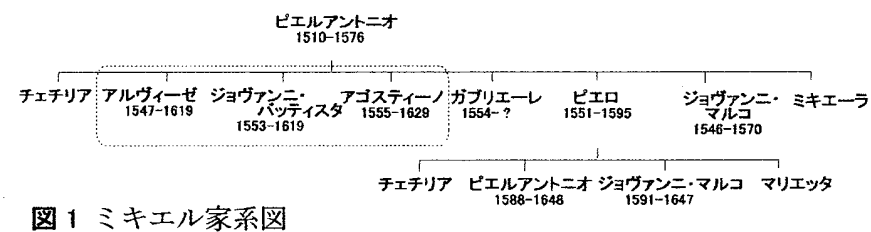

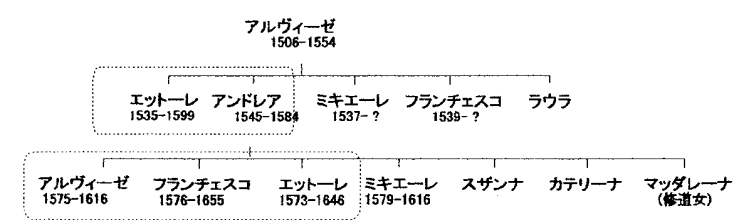

図 2 トロン家系図

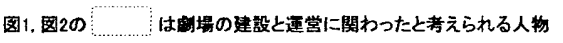

された劇場解体の指示も同じくアルヴィーゼとその兄弟に対して出

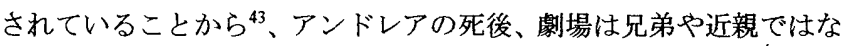
くまだ幼かった息子が相続したと考えられる。

以上のことから、この 2 つの劇場は複数の貴族による共同出資で 運営されたのではなく、ミキエル家、トロン家礼という単独貴族によ るもので、その中でも極めて近しい少数の人物によって所有、運営 されたことが確認できる。

\section{4 上演の主体と目的}

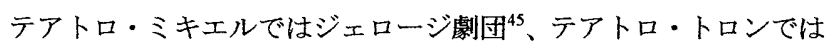
コンフィデンティ劇団46が雇われたことは、関連する先行研究におい ても言及されている ${ }^{47}$ 。特にコメディア・デッラルデの演で人気 があったこの 2 つの劇団は、両劇団の間で団員の移動が頻繁にみら れ、1583 年には一部が合併してウニーティ劇団として活動している。 また、共に他都市の貴族や有力者が催す祝祭や宴席に頻繁に招かれ、 1574 年にフランスのアンリ三世がヴェネツィアを訪問した際には、 ジェロージ劇団による上演が行われたことが知られている。アンリ 三世自らの要望でミラノから呼ばれた劇団は、カ・ジュスティニア ン、カ・フォスカリ、パラッツォ・ドゥカーレ内の大評議員の間に おいて政府が組織した晚餐会や祝賀会で、牧歌劇や喜劇、悲劇の上 演をおこなった ${ }^{49}$ 。一方公証人モンドのもとで作成された文書からは、 テアトロ・ミキエルの建設にあたりジェロージ劇団の役者の側が劇 場を建設・所有したアルヴィーゼ・ミキエル兄弟に対し多くの注文を 出したことがわかる。その内容は、全てアルヴィーゼ・ミキエル兄弟 の資金によって「喜劇を上演する専用の場所」が建設され、そこに は舞台背景と有料で賃貸する 200 個のボックス席がつくられること、 そのボックス席のうちひとつは画家ヤコポ・ティントレットに、も うひとつは建築家フランチェスコ・ザンベルランに無償で貸すこと、 劇場には役者のための住宅 4 件を併設させること等である。またそ の引き換えとしてアルヴィーゼ・ミキエル兄弟は 2 つのボックス席 を無償で使用でき、さらにジェロージ劇団は今後ヴェネッィアにお いてテアトロ・ミキエル以外では上演しないと記されている。劇場が 実際どのような形態で害現したのかを詳細に伝える史料は見つかっ ていないため、役者による要求がどの程度実現したのかは不明であ る。しかし、この劇場には有料で貴族に賃貸するボックス席が多数 あり役者の為の住宅が併設されるなど50、くつかの要求が実現した 事実が建設後に記された複数の記述から明らかである゙1。

また同文書の中には、アルヴィーゼ・ミキエル兄弟が毎晚の興行収 入の 12 分の 1 あるいは 13 分の 1 とそれに加えてボックス席の賃貸 によって得る収益の半分を得ることができるとしている。上演によ る残りの収益を誰が得たのか明記されていないが、劇団あるいは役 者個人が得た可能性が十分考えられる。

フランチェスコ・モンドによるこの文書を含め、劇場建設当初に 記された史料から 2 つの劇場は喜劇上演を目的として建設されたこ とが明らかである された後の 1585 年、ジェロージ劇団は同委員会に直接文書を送り、 牧歌劇、悲劇と非常に真面目な喜劇に限ると約束したうえで上演許 可を強く求めている53。これは役者らが当時特に厳しく監視されてい た喜劇上演の代わり、十人委員会にとり比較的受け入れやすかった 牧歌劇や悲劇という譲歩策を提案したと考えることができる。以上 
からジェロージ挀団にとって自ら建設を主導したテアトロ・ミキエ ルには、演目を変えてまで上演する何らかの魅力があり、それがボ ックス席の貨貸と興行から得る収入だった可能性が考えられる。

また、エットーレ・トロンがコンフィデンティ劇団の人気役者ペド ロニーノを迎え入れたいとしたエステ家のアルフォンソニ世に送っ た手紙には、貴族らから手付金として約 1000 ドゥカーティを得て上 演を行っていることが記され、ペドロニーノを引き抜くことによっ て劇団を解体させ、テアトロ・トロンでの上演を妨げないよう願い出

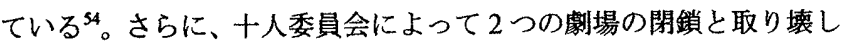
が通告された 1586 年にアルヴィーゼ・トロンがドージェとその顧問 に宛てた書簡にはトロン家が極めて困笨していると繰り返し書かれ、 劇場再開場の許可を求めている ${ }^{55}$ 。以上のことから劇場の興行によっ て得る収入が、貴族にとっても重要であった可能性が考えられる ${ }^{56}$ 。

\section{5 まとめ}

本稿ではヴェネツィアのサン・カッシアーノ地区に建設されたテ アトロ・ミキエルとテアトロ・トロンについて、劇場を所有した貴 族と役者に着目し、先行研究で使用されてきた史料の再精査をおこ なった。さらに公証人文書、書簡等より個人的な内容が記される原 史料を長期にわたりヴェネツィア国立古文書館で涉殍し、建設と上 演の様相を検証した。本稿が明らかにしたのは以下の点である。

1) 2 つの劇場は 1581 年に常設の劇場として建設された。しかし役 者によって書かれた喜劇上演の許可を嘆願する内容の手紙や、十 人委員会の議事録に記されているたび重なる喜劇上演の不許可か ら、劇場が閉鎖する 1586 年までの間で実際に上演が行われたのは、 開場加 1582 年 12 月 17 日までであったと考えられる。

2) 2 つの劇場はそれぞれミキエル家、トロン家といった単独の貴族 によって建設・運営された私設劇場であり、貴族と役者が有料上 演によって収入を得ることをひとつの目的とした劇場であった。 3) テアトロ・ミキエルの建設・運営に関してジェロージ劇団が強い 発言権を持っており、興行収入の大半は劇場建設に出資したミキ エル家ではなく、ジェロージ劇団あるいは役者個人に分配された 可能性がある。また、ジェロージ劇団と緊密なつながりがあるコ ンフィデンティ劇団によって上演が行われたテアトロ・トロンに おいても類似する状況にあったと考えられる。

以上から、ヴェネツィアで建設された 2 つの劇場は政府の庇護を 得ない貴族と役者による、興行収入を得ることをひとつの目的とし た劇場であり、君主や為政者個人の娱楽や祝祭を豪華に演出するた めに建設された同時期における他都市の劇場とは目的が異なること が明らかになる。当時すでにトスカーナ大公国という領域国家の首 都となっていたフィレンツェのように祝祭や演劇が君主の権力を誇 示する政治的な役割を持つ場合、その空間は一流の建策家を雇い、

豪華な舞台として演出されることが多かった。しかしヴェネツィア のように劇場が興行主による公共施設として有料上演を行う場合は、 必然として経済効果が重要視されることになる。後の $17 \cdot 18$ 世紀に 各地で建設されたオぺラ劇場はその結果としての現象である。

16 世紀後半、いまだ共和制を維持し君主等の特定の人物に権力が 集中することのなかったヴェネツィアだからこそ劇場は政治的目的 のみと強く結びつくのではなく、娛楽のための場であり、また興行 収入を得ることをひとつの目的とした劇場が誕生したのではないか
と考える。またヴェネツィアでは、既に 16 世紀前半から仮設劇場に おいて有料上演が行われていることからも ${ }^{57}$ 、有料上演という対象は 地中海貿易から本土における土地所有への資本の移行 ${ }^{58}$ 、毛織物、印 刷物、奢侈品をはじめとする手工業の隆盛等、経済構造が大きく転 換した 16 世紀ヴェネツィアにおいて貴族が期待した新たな収入のひ とつであった可能性が考えられる59。すなわち、このようなヴェネツ イア固有の社会的特質の中で誕生したサン・カッシアーノ地区の $2 つ$ の劇場の建設は、劇場が有力貴族や君主による政治的プロパガンダ と結びつくことなく、貴族や上層市民のための娛楽の場を提供する ことで収入を得ようとする 17 世紀に向けた過渡的状況を示している のである。

注

1) 特に 1580 年代は顕著で、ヴィチェンツァのテアトロ・オリンピコ、フィレ ンツェのウフィッツィ内の劇場、サッビオネータの劇場等が完成した。そ の他 16 世紀イタリアにおける劇場の誕生については以下を参照。Attolini, F., Teatro e spettacolo nel Rinascimento, Bari, 1988.; Il teatro italiano del Cinquecento, a cura di Magagnato, L., Mantova, 1980.

2) 建築家ヤコポ・サンソヴィーノの息子。フランチェスコ・サンソヴィー， については以下を参照。Bonora, E., Ricerche su Francesco Sansovino: imprenditore librario e letterato, Venezia, 1994.

3) Sansovino, F., Venetia città nobilissima et singolare, Venezia, 1581, cc.75r.-v., 以下拙訳「この教会 (サン・カッシアーノ教会) からわずかに離れたとこ ろに、巨額を投じて建設された実に美しい2つの劇場がある。そのうち一 方は棈円形もう片方は円形をし、大人数を収容できる。」

4) サン・カッシアーノ地区の 2 つの劇場以外のヴェネツィアの劇場としては テアトロ・ディ・サン・モイぜ(1613 年)、テアトロ・ヴェンドラミン(1622 年)がある。当時の記述等から、サン・カッシアーノ地区の劇場と同時期 にヴェネツィアに建設された劇場は存在しなかったと考えられる。

5) Venturi, L., Le compagnie della calza (sec.XV-XVl), Nuovo Archivio Veneto, vol.XVIII(1908), pp.161-221.; vol.XIX(1909), pp.140-231.

6) Padoan Urban, L., Teatri $e$ "Teatro del Mondo" nella Venezia del cinquecenteschi, Arte Veneta, 1966, pp.137-146.

7) Padoan Urban, L., Le Compagnie della Calza: edonismo e cultura al servizio della politica, Quaderni Veneti, 6 dicembre, 1987, pp.111-127

8) Muraro, M.T., La festa a Venezia e le sue manifestazioni rappresentative:le compagnie della calza e le momarie, Storia della Cultura Veneta vol.3/11I, Vicenza 1981, pp.315-341.

9)その他、16 世紀ヴェネッィアの演劇・祝祭に関しては以下の文献にも言及 が多い。Guarino, R., Teatro e mutamenti: rinascimento e spettacolo a Venezia, Bologna, 1995.; Padoan,G., La commedia rinascimentale veneta, Vicenza, 1982.; Tamassia Mazzarotto, B., Le feste veneziane: i giochi popolari, le cerimonie religiose e di governo, Firenze, 1961.

10) Giazotto, R., La guerra dei palchi, Nuova Rivista Musicale Italiana, II(1967), pp.245-286.; III(1967), pp.465-508.; IV(1969), pp.906-933.

11) I teatri pubblici di Venezia: secoli 17-18, a cura di Zorzi, L., Venezia, 1971

12) Mangini, N., I Teatri di Venezia, Venezia, 1974.

13) Mancini, F., et al., I Teatri di Venezia, tomo I, Venezia, 1996

14) Johnson, E.J., The short, lascivious lives of two venetian theaters: 1580-1585, Renaissance Quarterly, vol.LV(2002), pp.936-968.

15) Archivio di Stato di Venezia(以下 ASVe), Giudici del Piovego, b.86. 1762 年加 ら 1763 年に建築家 $\mathrm{F}$. ボニョーロによって作成された数地の実娜図、計 画案、実施案等の史料。Mancini, F., et al., op.cit.,pp105-114.を参照。

16) 筆者は 1579 年 9 月 5 日から 1586 年 8 月 30 日までの元老院の議事録 Senato Terra, Registro を調查した。

17） 1310 年に起こったクィリーニ・ティエポロの反乱をきっかけに都市の氾濫 や陰謀事件を防ぐ目的と犯罪の事後処理のために設立された機関。16 世紀 には財政、商業、都市の風紀に至る幅広い事柄の取り締まりを担った。

18) Sforza, G., F.M.Fiorentini ed i suoi contemporanei lucchesi, Firenze, 1879, pp.793-806.

19） 16 世紀の建築物的特徴を知るために有益な史料として道路・運河など公共 工事を管理した都市諸施設監督官 Provveditori di Comune、公共霰查官 Giudici del Piovego,などが知られているが、この劇場が存在した期間は史料 が大きく久落し、現存している史料にも記述は残されていない。また筆者 は4 人の委員を中心に建設とその後の訴訟を扱う Quattro Ministeriali と呼 ばれる機関の 1579 年から 1587 年までの記録を調查したが、ここにも $2 つ$ の劇場に関する件は見られなかった。

20) 当時のヴェネツィアの暦では 3 月 1 日から 2 月 28 日までを 1 年とするが、 
本稿では便宜上すべての日付を現在の暦に置き換えた。

21) ASVe. Notarile Atti, b.8317, cc.106v.-107v.,

22) この 4 人のうちパスクワーティを除く 3 人は、許可なくベルガモにて上演 したとの理由でテアトロ・ミキエル建設直前にマントヴァとその領土内か ら追放されている。Lea, K.M., Italian popular comedy: a study in the commedia dell'arte, 1560-1620, with special reference to the English stage, vol.I, Oxford, 1932, p.234.

23）ボローニャ出身の役者で、アルレッキーノを演じた。Bartoli, F., Notizie Istoriche de' comici italiani che fiorirono intorno all'anno 1500 fino a giorni presenti, opera ricercata, raccolta, ed estesa da Francesco Bartoli, Padova, 1782, p.240.

24) パドヴァ出身。ジェロージ劇団のインナモラート役として重要な役者。才 ラツィオ・ノービリとも名乗っていた。Enciclopedia dello spettacolo, vol.II, fondata da Silvio D'Amico, Roma,1975, pp.1191-1192.

25) パドヴァ出身で、アドリアーノ・ヴァレリーニと共にジェロージ劇団で活 動した役者。パンタローネを演じた。 Rasi, L., I comici italiani, vol.II, Firenze, 1899, pp.226-235.; Bartoli, F., op.cit, p80.

26) ヴェローナ出身。フランチェスコ・アンドレイーニと共にジェロージ劇団 に参加。1571 年以降数度にわたりフランスでの上演に加わった。また 1583 年にはコンフィデンティ劇団を合併して、ウニーティ劇団の結成を率引し た。Enciclopedia dello spettacolo, vol.IX, fondata da Silvio D'Amico, Roma, 1975, p.1401.; Bartoli, F., op.cit, pp.259-261.; Rasi, L., op.cit.,vol.II, pp.616-622.

27) 筆者は 1579 年から 1581 年にかけてヴェネッィアで登録されていた公証人 102 人による文書、計 146 箱をヴェネッィア国立古文書館において調查し たが、テアトロ・トロンの建設以前に関わる文書は見つからなかった。

28) Archivio di Stato di Modena, Archivio per Materiali, Drammatica, Minute di Lettere a comici, busta unica., この史料については以下を参照。Solerti, A., Lanza, D., Il teatro ferrarese nella seconda metà del Secolo XVI, Giornale Storico delia Letteratura Italiana, vol.XVIII(1891), Torino, pp.148-185.; Mancini, F., et al., op.cit, pp.98-99.

29) ASVe, Consiglio dei Dieci, Parti Comuni, r.36, c.9r.; Sforza, G., op.cit, pp.798-799.

30) ASVe, Consiglio dei Dieci, Misti, r.32, c.55v.; Bistort, G., Il magistrato alle pompe nella repubblica di Venezia, miscellanea di storia veneta, serie terza, tomo V, Venezia, 1912, p.225-231.

31）上演が禁止された期間の公証人文書にも許可を得ずに上演を行った劇団 に関する史料が複数残っている。

32) ASVe, Consiglio dei Dieci, Parti Comuni, Filza, b.158. 以下要約「他の劇団が 不法に上演した一方、私たちは許可なく上演を敢行することはなかった。 不道徳な問題が生じないよう、牧歌劇、悲劇、その他非常に真面目な喜劇 だけを上演することを堑い、カーニバル期間中の上演が許可されるよう想 願する。」Johnson, E.J., op.cit.p.950

33) 劇団の巡業地については以下を参照。Winifred; S., The commedia dell'arte, New York, 1964.; Taviani, F., Il segreto della commedia dell'arte : la memoria delle compagnie italiane, Firenze, 1982

34) ASVe., Consiglio dei Dieci, Parti Comuni, Filza, b.161.; Johnson, E.J., op.cit., pp. 952-954

35) ASVe. Consiglio dei Dieci, Parti Comuni, r.37, c.81v.; N.マンジー二は2つの劇 場では開場直後散発的な上演がおこなわれたに過ぎないとしている。また 閉場年についてはテアトロ・ミキェルを 16 世紀末、テアトロ・トロンに 関しては具体的に言及していない。F.マンチーニらはテアトロ・ミキエル の閉場年を 1583 年以降、テアトロ・トロンについては開場後は 1607 年ま で記録がみられないとしている。一方で E.J ジョンソンは十人委員会によ る劇場解体の通達をもとに 1586 年に閉鎖された可能性を指摘した。 Johnson, E.J., op.cit., p.954.

36) 劇場と役者用の住宅を申告している。ASVe., Dieci Savi alle Decime in Rialto, Condizioni di Decima, Dorsoduro, b.172, fasc.1376.; Mangini, N., op.cit., p.22.

37) Ibid，複数の兄弟をあらわす fratelli と記されていることから、アルヴィー ゼを含めた 3 人以上の連名であることがわかる。

38) ASVe., Notarile, Testamenti, b.1244, fasc. 439

39) ASVe., Notarile, Testamenti, b.347, fasc. 7 .

40）おそらく財産の多くがピエロに相続されたのは、ミキエル家の中で息子が いたのはピエロのみであったからと考えられる。

41) ASVe., Dieci Savi alle Decime in Rialto, Condizioni di Decima, b.158, fasc. 905. Mangini, N., op.cit., p.24.

42）E.J.ジョンソンはアルヴィーゼ・トロンがまだ幼かったことを指摘し、叔 父のエットーレが代筆した可能性を示している。Johnson，E.J., op.cit.pp.952-953.

43）兄弟のうち誰を指すのかは不明だが、1607 年にテアトロ・トロンが再開場 した際にはその運営に、ェットーレ、フランチェスコが関わっていること から、アルヴィーゼを含む 3 人であったと考えられる。

44）ミキエル家とトロン家に関し、F.マンチーニと E.J.ジョンソンはドージェ を輩出した有力家系であったとしている。しかし 1470 年代にドージェを
出したトロン家とサン・ベネデットのトロン家、12 世紀までに複数のドー ジェを輩出したミキエル家とサン・バジーリオのミキエル家は同姓である

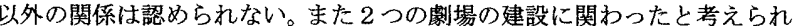
る人物の中に政府の要職に就いたものは確認できない。同姓を有するヴェ ネッィア貴族とその結束に関しては、Crouzet Pavan, É., Venezia trionfante: gli orizzonti di un mito, Torino, 2001, pp.265-267; 高田京比子『都市国家ヴェ ネツィアに扩ける貴族の親族集団』史林 75(2), 1992,pp.145-183.

45）特定の贵族に属さなかったが国家君主たちから援助を受けていた。また海 外に巡業したことも知られている。この劇団は”美徳・名声・名誉”をモッ トーに喜劇、悲喜劇、悲挀、インテルメッツォ、牧歌劇など即興劇から台 本のある作品まであらゆる種類の演劇を上演した。ジェロージ劇団につい ては以下を参照。Ughi,S., Di Adriano Valerini, di Silvia Roncagli e dei comici gelosi, Biblioteca Teatrale, III(1973), pp.147-154.; Marchi, G.P., L'esperienza teatrale di Adriano Valerini, La commedia dell'arte tra cinque e seicento in Francia e in Europa, Atti del Convegno Internazionale di Studio, Fasaro, 1997, pp.173-180; Lea, K.M. op.cit.

46) 北イタリアの主要な町を中心に活動とした。なかでも 1570 年代後半から 80 年代にかけてはマントヴァと関係が深く、サン・カッシアーノの劇場が 閣場した直後にはゴンザーガ家の専属の劇団となったことが知られてい る。 Lea, K.M., ibid.; Richards, K., ibid., pp.64-65.

47) D'Ancona, A., L'origine del teatro italiano, vol.II, Torino, 1891, p.484.; Solerti, A., et al., op.cit.; Mangini, N., op.cit, pp.23-25.

48）旅回りをする劇団による即與性を重視した喜劇。以下を参照。Apollonio, M., Storia della commedia dell'arte, Milano, 1930; Ferrone, S. Attori mercanti corsari, la commedia dell'arte in Europa tra cinque e seicento, Torino 1993.; Povoledo, E., I comici professionisti e la commedia dell 'arte, caratteri, tecniche, fortuna, in Storia della Cultura Veneta, vol.4/I, Vicenza, 1983

49) 劇団の招致と上演については以下を参照。ASVe, Secreta, Materie Miste Notabili, Filza, b.37.; Nolhac, P., Solerti, A., Il viaggio in Italia di Enrico III, re di Francia, e le feste a Venezia, Ferrara, Mantova e Torino, Torino 1890.

50) ASVe., Dieci Savi alle Decime in Rialto, Condizioni di Decima, b.158, fasc. 905 ,

51) Biblioteca Nazionale Marciana, Ms. Marc., it., VII, 335 (8232), c.38 v.; Mancini, F., et al., op.cit.; Solerti, A., et al., op.cit.

52）通常十人委員会の議事録、十分の一税報告書等では劇場という言菜を使用 せずに「喜劇上演のための場所」と表現されている。

53) ASVe., Consiglio dei Dieci, Parti Comuni, Filza, b.158

54) ASMo., Archivio per Materiali, Drammatica, Minute di Lettere a Comici, busta unica.; Solerti, A., Lanza, D., op.cit.,pp.148-185.; .Mancini, F., et al., op.cit, pp. $98-99$.

55) ASVe., Consiglio dei Dieci, Parti Comuni, Filza, b.161: 以下要約「大家族であ るトロン家の兄弟は、先の激しい戦争により困窮した極めて惨めかつ不幸 な一家であるということをここに申し上げます。私達の祖先は共和国に対 する多大なる信用と信仰に基づき、一家にとって可能な限りの力を結集し 膨大な資金をか计喜劇上演のための場所をつくりましたが、その後まもな く都市諸施設監督官とコッレージョに支払う経费の增大等により多額の 借金を負うことになりました。さらに喜劇には淫らで不真面目な言莱の使 用がみられ、秩序を乱すとして、惨めで貧しい私详は劇場での上演を禁止 されるに至りました。これは上演中には常にボックス席の後部を開放し、 役者らが最大の誠実さと質素さを持ち、極好分別のある喜劇、牧歌劇、 悲劇を上演し、いかなる騒ぎも中穓も起こらないよう厳しく監視すること で防げることで、喜劇は街中で望まれている娛楽でありましょう。ローマ やボローニヤにおいて喜劇が上演されているのに、なぜ貧しく不幸な私達 には㷫められないのでしょうか。カーニバルの期間中、劇場での喜劇上演 を許可いただけますようお願い申し上げます。」

56） 2 つの劇場が貴族を対象とし、高額な入場料を徵収していたこと等から慈 善、䝰安事業として建設された可能性は低いと考える。劇場建設と上演の 目的としてミキエル家、トロン家による社交の目的があった可能性は考え られる。これに関し筆者はミキエル家、トロン家のコンパニーア・デッラ・ カルツァへの参加、その会員との関与、婚姻、政治活動、スクオーラ・グ ランデへの参加等について調查したが、明確に襄付けるような史料は見つ からなかった。

57）有料上演については以下を参照。Ferrone, S., op.cit., Torino, 1993, pp.53-55.; Padoan, G., op.cit, pp.33-37.; Mancini, F., et al., op.cit.pp.15-17.

58) Pullan, B., Occupation and investments of the venetian nobility, ed. Hale, J.R. Renaissance Venice, London, 1973, pp.379-408.; 和栗珠里『土地所有とヴェネ ツィア富裕階級のメンタリティーの変化』文化史学 45 号, 1989 年, pp.153-172

59)16 世紀ヴェネツィア商業への打撃上回復、産業基盤の変化についてはLane, F.C. Venice: a maritime republic, Baltimore and London, 1973, op.cit., p.310-312.; 藤内哲也『近世ヴェネツィアの権力と社会』昭和堂, 2005 年, pp.3-14.; 参照。 